DOI: $10.6060 / \mathrm{mhc} 130223 \mathrm{k}$

\title{
Synthesis of a Novel Crown-Fused Tetraphenylporphyrin
}

\author{
Vasily E. Kotsuba ${ }_{1}{ }^{@}$ Nadezhda M. Kolyadina, ${ }^{a}$ Anatoly T. Soldatenkov, ${ }^{a}$ \\ and Victor N. Khrustalev
}

Decicated to Academician Irina P. Beletskaya on the occasion of her Anniversary

\author{
aPeoples' Friendship University of Russia, 117198 Moscow, Russia \\ ${ }^{\mathrm{b}}$ Nesmeyanov Institute of Organoelement Compounds, 119334 Moscow, Russia \\ @Corresponding authorE-mail: vasilyk@yandex.ru
}

A modified Lindsey procedure was employed to obtain a novel tetraphenylporphyrin derivative bearing two fused crown ether rings. X-Ray analysis was used to determine the structure of the compound.

Keywords: Porphyrins, crown ethers, pyrrole, 1,8-bis(2-formylphenoxy)-3,6-dioxaoctane, condensation.

\section{Синтез нового краун-сочленённого тетрафенилпорфирина}

\author{
В. Е. Коцюба, ${ }^{\mathrm{a}}$ Н. М. Колядина, ${ }^{a}$ А. Т. Солдатенков, ${ }^{a}$ В. Н. Хрусталёв ${ }^{\mathrm{b}}$ \\ Посвящается Академику Ирине Петровне Белецкой по случаю её юбилея
}

\author{
ароссийский университет дружбы народов, 117198 Москва, Россия \\ ' Институт элементорганических соединений им. Несмеянова, 119334 Москва, Россия \\ @E-mail:vasilyk@yandex.ru
}

\begin{abstract}
Новое производное 5,10,15,20-тетрафенилпорфирина, содержащзее два сочленённых краун-эфирных фрагмента, было получено по модифицированной методике Линдси. Строение полученного соединения было подтверждено методом РСА.
\end{abstract}

Ключевые слова: Порфирины, краун-эфиры, пиррол, 1,8-бис(2-формилфенокси)-3,6-диоксаоктан, конденсация.

Structure modification of the tetrapyrrolic macrocycles with additional coordinating groups allows fine-tuning of the affinity of these compounds to certain metal ions, their solubility in various fluids, the intensity of fluorescence and other physico-chemical properties. The resulting derivatives of porphyrins and phthalocyanines can be used for the creation of improved chemoreceptors, sensors, catalysts, components of nano-devices. ${ }^{[1]}$ Such molecules can be obtained, for example, by introduction of crown ether moieties, ${ }^{[2-4]}$ which can be connected to the tetrapyrrolic core in a number of ways. ${ }^{[5]}$ The aim of the present work was to obtain a novel crown- annulated porphyrin 2 using 1,8-bis(2-formylphenoxy)-3,6dioxaoctane (1) as the starting material.

Our first attempt was to use the classic Adler-Longo procedure $^{[6]}$ for the synthesis of 2 . However, only trace amounts of the desired compound were detected by LC/MS analysis in the resulting material. Surprisingly, using the Lindsey procedure, ${ }^{[7]}$ which employs considerably milder reaction conditions - performing the condensation in a dilute solution with the consequent oxidation with chloranil - led to a similar result. However, when we modified the latter procedure by using peroxyacetic acid or Oxone as an 


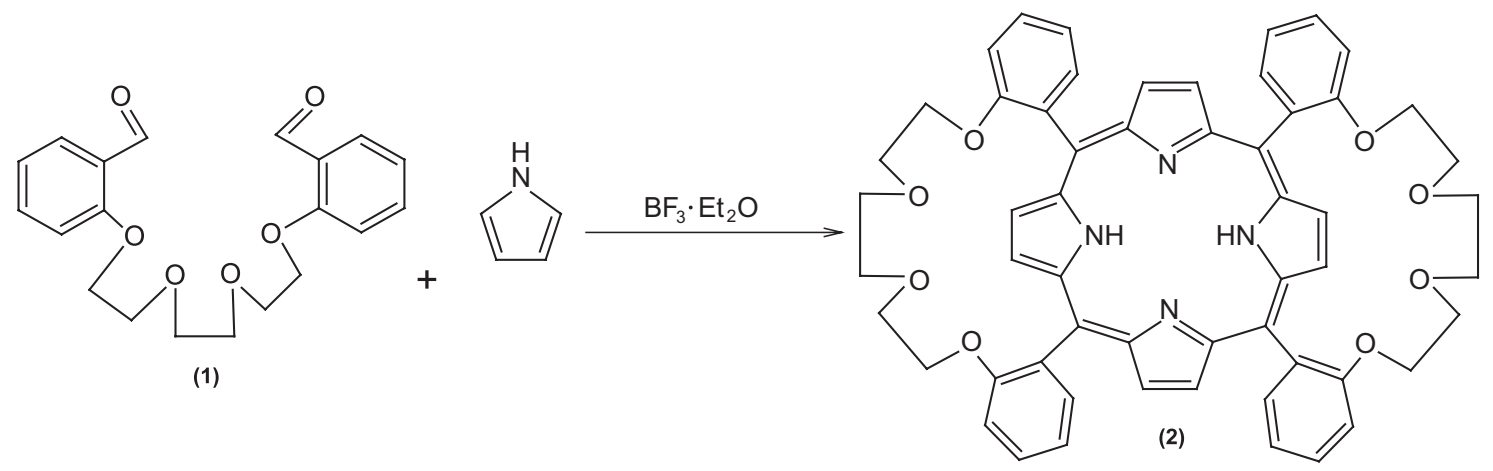

oxidative agent, compound $\mathbf{2}$ was successfully obtained as a mixture of two isomers (two peaks are observed in LC/ MS spectrum) with $11 \%$ yield. Due to the difficulties of chromatographic separation of the isomers, currently we have been able to isolate analytically pure samples only of one of them.

The condensation of pyrrole with dialdehyde $\mathbf{1}$ may result in the formation of several geometric isomers: the crown ether voids can be positioned either on the same or on the opposite sides from the plane of the porphyrin core, besides, the crown ether threads can connect the diagonal phenyl rings. We performed an X-Ray structure study, which defined the geometry of the isolated isomer of compound 2 to be cis $\alpha \beta$ strapped (according to nomenclature proposed $\mathrm{in}^{[8]}$ ). The detailed X-Ray data will be published in a separate paper.

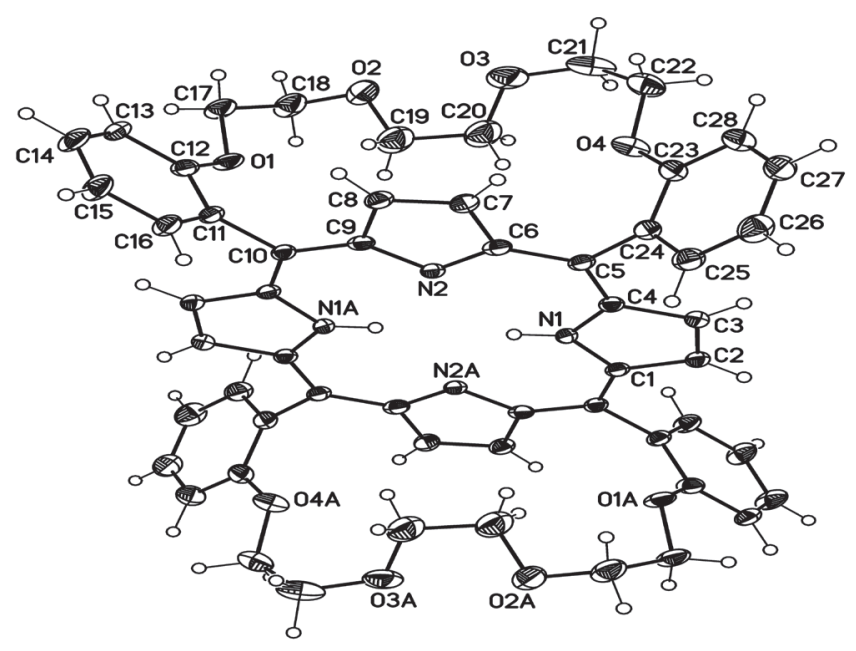

Figure 1. Structure of the crown-porphyrin (2) according to X-ray study data.

In acetonitrile solution, the Soret band of compound (2) is observed at $414 \mathrm{~nm}$, while the Q-bands correspond to 511, 542, 587 and $643 \mathrm{~nm}$ absorbance peaks. Thus, the UV-Vis spectrum of (2) belongs to the classic type of the porphyrin core spectra. ${ }^{[9]}$

The NH stretching vibrations result in a strong IR band at $3430 \mathrm{~cm}^{-1}$. The skeletal vibrations of the porphyrin ring appear at 1241 and $1117 \mathrm{~cm}^{-1}$. A band of moderate intensity at $1595 \mathrm{~cm}^{-1}$ corresponds to $\mathrm{v}(\mathrm{C}-\mathrm{C})$ of the substituted benzene rings, and a weak band at $3068 \mathrm{~cm}^{-1}-$ to $v(\mathrm{C}-\mathrm{H})$. Out-of-plane deformation vibrations of methyne carbon bridges appear as a band at $753 \mathrm{~cm}^{-1}$.
Eight protons of the $\beta$-pyrrole carbons give a doublet signal at $8.70 \mathrm{ppm}(J=16.0 \mathrm{~Hz})$. The NH-protons appear as singlet at $-2.70 \mathrm{ppm}$ with a strongly diminished integral intensity, which corresponds to literature data. ${ }^{[9]}$ Six signals that belong to the $-\mathrm{O}-\mathrm{CH}_{2} \mathrm{CH}_{2}-\mathrm{O}$ - groups have a total integral intensity of 24 protons, and are observed in the upfield region $(0.89-4.08 \mathrm{ppm})$. The aromatic protons of the disubstituted benzene rings resonate at 7.21-8.09 $\mathrm{ppm}$ and form an ABCD-system $\left({ }^{3} J=8.8,7.6,8.0\right.$ and $7.2,{ }^{4} J=1.8$ and $1.6 \mathrm{~Hz}$ correspondingly).

The ${ }^{1} \mathrm{H}$ NMR spectra were recorded on a Bruker WP-400 spectrometer. The UV-Vis spectra were studied in acetonitrile on a Varian Cary Scan 50 instrument, the IR spectra were obtained in $\mathrm{KBr}$ pellets on an Infralum FT-801 Fourierspectrophotometer. The elemental analysis was carried out on a Eurovector EA-3000 analyzer. LC/MS analysis was performed using an Agilent 1100 series chromatograph equipped with Agilent 1100 series DAD (wavelength $420 \pm 10$ nm was used for detection), Sedex 75 ELSD and Agilent LC/ MSD VL mass spectrometer (ionization in APCI interface). The X-ray structure study was conducted on a Bruker SMART 1000 CCD automated diffractometer, with $\mathrm{MoK}_{\alpha}-$ radiation, graphite monochromator, $\theta$ - and $\omega$-scan. The crystallographic data can be found in Cambridge Structural Database (CCDC 891970).

The following solvents and reagents were used in the course of the present study. Pyrrole, triethylamine, boron trifluoride etherate, aluminium oxide (basic) were purchased from Alfa Aesar. Oxone $\left(2 \mathrm{KHSO}_{5} \cdot \mathrm{KHSO}_{4} \cdot \mathrm{K}_{2} \mathrm{SO}_{4}\right)$ was purchased from Acros Organics. Pyrrole was purified before use by eluting its dilute solution in dichloromethane through a short alumina column and then distilling off the solvent. All other reagents were used as received. Dialdehyde $\mathbf{1}$ was synthesized by a published procedure. ${ }^{[10]}$ Dichloromethane from "Chimmed" company was purified by reflxing it for 1.5 hours over phosphorus pentoxide with the consequent distillation from a fresh portion of $\mathrm{P}_{2} \mathrm{O}_{5}$. Acetonitrile (HPLC gradient grade) from Panreac was used for spectrophotometry as received.

5,10:15,20-Bis [8,1-(3,6-dioxa)octanediyl-2,1(phenoxy)]porphyrin (2). Nitrogen is bubbled for $10 \mathrm{~min}$. through a solution of $0.89 \mathrm{~g}(2.5 \mathrm{mmol})$ of dialdehyde 1 and $0.34 \mathrm{~g}(5 \mathrm{mmol})$ of pyrrole in $500 \mathrm{ml}$ of dichloromethane. Then, $\mathrm{BF}_{3} \cdot \mathrm{Et}_{2} \mathrm{O}(5 \mathrm{mmol}, 0.7 \mathrm{ml})$ is introduced and the reaction vessel is protected from light. The mixture is magnetically stirred under an atmosphere of nitrogen for 1.5 $\mathrm{hrs}$, then excess of triethylamine is added ( $2 \mathrm{ml}, 14 \mathrm{mmol})$. After 10 min of stirring $200 \mathrm{ml}$ of $5 \%$ aqueous Oxone solution is added and the stirring is continued for extra $40 \mathrm{~min}$. The 
mixture is then transferred to a separatory funnel, the organic layer is separated and washed two times with equal amounts of water. After drying with $\mathrm{MgSO}_{4}$, the dichloromethane extract is evaporated and the residue is purified on basic alumina, eluting with ethyl acetate. Compound 2 was obtained as a dark-purple lustrous powder $(0.124 \mathrm{~g}, 0.137 \mathrm{mmol}$, $11 \%$ ). M.p. $>300{ }^{\circ}$ C. Found: C 74.10; H 5.33; N $6.15 \%$. $\mathrm{C}_{56} \mathrm{H}_{50} \mathrm{~N}_{4} \mathrm{O}_{8}$ requires: $\mathrm{C} 74.15 ; \mathrm{H} 5.56$; $\mathrm{N} 6.18 \% . \mathrm{m} / \mathrm{z}$ (APCI) (\%): $907(100)\left[(\mathrm{M}+\mathrm{H})^{+}\right]$. IR (KBr) $v_{\max } \mathrm{cm}^{-1}: 3430 \mathrm{~s}, 3068$ $\mathrm{w}, 1595 \mathrm{~m}, 1241 \mathrm{~m}, 1117 \mathrm{~m} 753 \mathrm{~m}$. UV-vis (acetonitrile) $\lambda_{\text {max }}$ nm (lge): 414 (5.24), 511 (4.02), 542 (3.66), 587 (3.58), 643 (3.36). ${ }^{1} \mathrm{H}$ NMR $\left(\mathrm{CDCl}_{3}, 363 \mathrm{~K}\right) \delta_{\mathrm{H}} \mathrm{ppm}:-2.70(2 \mathrm{H}, \mathrm{s}, \mathrm{NH})$, 0.89 and 1.15 (4H each, both s, Ar-O- $\left.\mathrm{CH}_{2}-\right)$, 2.58, 3.39, 3.95, 4.08 (4H each, all m, $-\mathrm{OCH}_{2} \mathrm{CH}_{2}-\mathrm{OCH}_{2} \mathrm{CH}_{2} \mathrm{O}-$ ), 7.21, 7.37, 7.74 and 8.09 (4H each, ABCD-system, ${ }^{3} \mathrm{~J}=8.8,7.6,8.0$ and $7.2,{ }^{4} J=1.8$ and $\left.1.6, \mathrm{H}_{\text {arom. }}\right), 8.73\left(8 \mathrm{H}, \mathrm{d}, J=16.0, \mathrm{H}_{\beta \text {-pyrrole }}\right)$.

Acknowledgements. The authors would like to thank Chembridge Corp. for the opportunity to use LC/MS analysis.

\section{References}

1. Engelkamp H., Nolte R.J.M. J. Porphyrins Phthalocyanines 2000, 4, 454-459.

2. Jahan M., Safari N., Khosravi H., Moghimi A., Notash B. Polyhedron 2005, 24, 1682-1688.

3. Özer M., Altındal A., Salih A., Bulut M., Bekaroğlu Ö. Tetrahedron Lett. 2008, 49, 896-900.

4. Birin K.P., Gorbunova Yu.G., Tsivadze A.Yu. J. Porphyrins Phthalocyanines 2006, 6, 931-936.

5. Even P., Boitrel B. Coord. Chem. Rev. 2006, 250, 519-541.

6. Adler A.D., Longo F.R., Finarelli J.D., Goldmacher J., Assour J., Korsakoff L. J. Org. Chem. 1967, 32, 476-476.

7. Lindsey J.S., Schreiman I.C., Hsu H.C., Kearney P.C., Marguerettaz A.M. J. Org. Chem. 1987, 52, 827-836.

8. Wagner R.W., Johnson T.E., Lindsey J.S. Tetrahedron 1996, 53, 6755-6790.

9. Mamardashvili N.Zh., Golubchikov O.A. Russ. Chem. Rev. 2001, 70, 577-606.

10. Levov A.N., Le Tuan Ahn, Komarova A.I., Strokina V.M., Soldatenkov A.T., Khrustalev V.N. Russ. J. Org. Chem. 2008, 44, 456-461. 